\title{
\begin{tabular}{c} 
AFRICAN \\
EAST-ASIAN \\
AFFAIRS \\
\hline THE CHINA MONITOR
\end{tabular}
}

\section{China and small-island developing states}

\begin{abstract}
By Richard L. Bernal* Executive Director for the Caribbean, Inter-American Development Bank *The views are those of the author and not those of the Inter-American Development Bank.
\end{abstract}

\section{Introduction}

China in recent years has dramatically increased its economic involvement with the global economy and expanded and consolidated its diplomatic and political ties across the world. China's actions are prompted by an amalgam of economic, political and security motives. This escalation and intensification of engagement is to be expected from an emerging superpower like China. The country's expanding reach has encompassed relations with small island developing states (SIDS), which some find to be an enigma given their apparently marginal if not irrelevant significance to a global superpower. For many developed countries and large developing countries, relations with small island developing states are an unavoidable inconvenience, which should entail minimal time and resources. Yet China has enhanced its relations with small island developing states and this is reflected in its increased

* The author is Executive Director for the Caribbean, Inter-American Development Bank; Honorary Professor, Sir Arthur Lewis Institute of Social and Economic Studies, University of the West Indies, Jamaica; and Senior Associate, Center for Strategic and International Studies. 
development assistance, provision of technical assistance, expansion of trade and the embryonic deployment of foreign investment and execution of infrastructure and construction projects. The driving force behind China's engagement is its rivalry with Taiwan for diplomatic recognition.

\section{Small Island Developing States}

The United Nations recognizes fifty-one countries as small island developing states of which thirty-eight are members of the United Nations. All of them are shown in Table 1. There is no single formally accepted definition of a small island developing state because size is a relative concept. A variety of criteria has been applied singularly (for example, population) (Commonwealth Secretariat/World Bank Joint Taskforce on Small States; 2009, Commonwealth Secretariat; 1997) or in combination (Bernal; 1998) (for example, GDP, population and land area). The World Bank and Commonwealth Secretariat employ a population threshold of 1.5 million to designate small states but include larger countries such as Jamaica because they share many of the characteristics of smallness. The nomenclature of small island developing state encompasses countries that are not islands such as Belize and even some such as Guyana, which have relatively large land areas. Small island developing states have similar structural characteristics, including small size, high degree of openness, concentration on a few exports, narrow range of resources, remoteness and environmental vulnerability. These tiny countries vary in size, land area, per capita income and GDP, as shown in Table 2. SIDS as a category of country was recognized in the United Nations in 1994 by the 


\section{AFRICAN \\ EAST-ASIAN \\ AFFAIRS}

THE CHINA MONITOR

Issue 1

August 2012

Programme of Action for the Sustainable Development in SIDS (Barbados Programme of Action). The UN subsequently established the Office of the High Representative for the Least Developed Countries, Landlocked Developing Countries and the Small Island Developing States in 2001.

\section{Table 1: Small Island Developing States}

\begin{tabular}{|l|l|l|l|}
\hline \multicolumn{2}{|l|}{ UN Members) } & $\mathbf{2 0}$ & Federated States of Micronesia \\
\hline $\mathbf{1}$ & Antigua and Barbuda & $\mathbf{2 1}$ & Mauritius \\
\hline $\mathbf{2}$ & Bahamas & $\mathbf{2 2}$ & Nauru \\
\hline $\mathbf{3}$ & Bahrain & $\mathbf{2 3}$ & Palau \\
\hline $\mathbf{4}$ & Barbados & $\mathbf{2 4}$ & Papua New Guinea \\
\hline $\mathbf{5}$ & Belize & $\mathbf{2 5}$ & Samoa \\
\hline $\mathbf{6}$ & Cape Verde & $\mathbf{2 6}$ & São Tomé and Principe \\
\hline $\mathbf{7}$ & Comoros & $\mathbf{2 7}$ & Singapore \\
\hline $\mathbf{8}$ & Cuba & $\mathbf{2 8}$ & St. Kitts and Nevis \\
\hline $\mathbf{9}$ & Dominica & $\mathbf{2 9}$ & St. Lucia \\
\hline $\mathbf{1 0}$ & Dominican Republic & $\mathbf{3 0}$ & St. Vincent and the Grenadines \\
\hline $\mathbf{1 1}$ & Fiji & $\mathbf{3 1}$ & Seychelles \\
\hline $\mathbf{1 2}$ & Grenada & $\mathbf{3 2}$ & Solomon Islands \\
\hline $\mathbf{1 3}$ & Guinea-Bissau & $\mathbf{3 3}$ & Suriname \\
\hline $\mathbf{1 4}$ & Guyana & $\mathbf{3 4}$ & Timor-Lesté \\
\hline $\mathbf{1 5}$ & Haiti & & \\
\hline
\end{tabular}

05 (C) Centre for Chinese Studies, Stellenbosch University All Rights Reserved. 
Richard L. Bernal

"China and Small-Island Developing States"

\begin{tabular}{|l|l|l|l|}
\hline $\mathbf{1 7}$ & Kiribati & $\mathbf{3 6}$ & Trinidad and Tobago \\
\hline $\mathbf{1 8}$ & Maldives & $\mathbf{3 7}$ & Tuvalu \\
\hline $\mathbf{1 9}$ & Marshall Islands & $\mathbf{3 8}$ & Vanuatu \\
\hline
\end{tabular}

Source: Alliance of Small Island Developing States (AOSIS)

What differentiates small island developing states from other small countries with which they share similar economic features is their environmental vulnerability. SIDS, where much of the land area and/or population is below 10 meters above sea level, are coastal societies, because in some cases most of the population, economic activity, infrastructure and habitation is on the coast. The situation makes SIDS highly susceptible to natural disasters and climate change. "The very existence of low-lying atoll nations, such as Kiribati, Maldives, Marshall Islands, and Tuvulu, is threatened by climate change-induced sea-level." (SIDS; 2010)

Table 2: Size of Small and Island Development States* in 2010

\begin{tabular}{|c|c|c|c|c|c|}
\hline & $\begin{array}{c}\text { Popula- } \\
\text { tion }\end{array}$ & $\begin{array}{c}\text { Surface } \\
\text { Area }\end{array}$ & $\begin{array}{c}\text { Popula- } \\
\text { tion } \\
\text { Density }\end{array}$ & $\begin{array}{c}\text { Gross } \\
\text { National } \\
\text { Income }\end{array}$ & $\begin{array}{c}\text { Gross Na- } \\
\text { tional In- } \\
\text { come per } \\
\text { capita }\end{array}$ \\
\hline $\begin{array}{c}\text { Thou- } \\
\text { sands }\end{array}$ & $\begin{array}{c}\text { Thousand } \\
\text { sq. km }\end{array}$ & $\begin{array}{c}\text { People per } \\
\text { sq. km }\end{array}$ & $\$$ millions & $\$$ \\
\hline $\begin{array}{c}\text { Antigua and } \\
\text { Barbuda }\end{array}$ & 89 & 0.4 & 199 & 939 & 10,610 \\
\hline $\begin{array}{c}\text { Bahamas, the } \\
\text { Barbados }\end{array}$ & 257 & 13.9 & 34 & 6,973 & 20,410 \\
\hline Belize & 345 & 23.0 & 15 & 1,288 & 3,740 \\
\hline
\end{tabular}




\section{AFRICAN EAST-ASIAN AFFAIRS

\begin{tabular}{|c|c|c|c|c|c|}
\hline Bhutan & 708 & 38.4 & 18 & 1,361 & 1,920 \\
\hline Cape Verde & 513 & 4.0 & 125 & 1,620 & 3,160 \\
\hline Comoros & 675 & 1.9 & 354 & 550 & 820 \\
\hline Djibouti & 879 & 23.2 & 37 & 1,105 & 1,280 \\
\hline Dominica & 74 & 0.8 & 98 & 367 & 4,960 \\
\hline Fiji & 854 & 18.3 & 46 & 3,085 & 3,610 \\
\hline Grenada & 104 & 0.3 & 306 & 580 & 5,560 \\
\hline $\begin{array}{c}\text { Guinea- } \\
\text { Bissau }\end{array}$ & 1,647 & 36.1 & 57 & 890 & 540 \\
\hline Guyana & 761 & 215.0 & 4 & 2,491 & 3,270 \\
\hline Jamaica & 2,712 & 11.0 & 249 & 12,892 & 4,750 \\
\hline Kiribati & 100 & 0.8 & 121 & 200 & 2,010 \\
\hline Maldives & 314 & 0.3 & 1,031 & 1,340 & 4,270 \\
\hline $\begin{array}{c}\text { Marshall } \\
\text { Islands }\end{array}$ & 62 & 0.2 & 339 & 187 & 2,990 \\
\hline Mauritius & 1,282 & 2.0 & 628 & 9,925 & 7,740 \\
\hline $\begin{array}{c}\text { Micronesia, } \\
\text { Fed. Sts. }\end{array}$ & 111 & 0.7 & 158 & 300 & 2,700 \\
\hline Palau & 21 & 0.5 & 44 & 133 & 6,460 \\
\hline Samoa & 179 & 2.8 & 63 & 524 & 2,930 \\
\hline $\begin{array}{c}\text { São Tomé } \\
\text { \& Príncipe }\end{array}$ & 165 & 1.0 & 170 & 199 & 1,200 \\
\hline
\end{tabular}


Richard L. Bernal

"China and Small-Island Developing States"

\begin{tabular}{|c|c|c|c|c|c|}
\hline $\begin{array}{l}\text { São Tomé } \\
\text { \& Príncipe }\end{array}$ & 165 & 1.0 & 170 & 199 & 1,200 \\
\hline Seychelles & 89 & 0.5 & 191 & 845 & 9,490 \\
\hline $\begin{array}{l}\text { Solomon } \\
\text { Islands }\end{array}$ & 536 & 28.9 & 19 & 552 & 1,030 \\
\hline $\begin{array}{c}\text { St. Kitts } \\
\text { and Nevis }\end{array}$ & 50 & 0.3 & 191 & 499 & 9,980 \\
\hline St. Lucia & 174 & 0.6 & 282 & 865 & 4,970 \\
\hline $\begin{array}{l}\text { St. Vincent } \\
\text { and the } \\
\text { Grenadines }\end{array}$ & 109 & 0.4 & 280 & 530 & 4,850 \\
\hline Suriname & 524 & 163.8 & 3 & 3,076 & 5,920 \\
\hline $\begin{array}{l}\text { Timor- } \\
\text { Leste }\end{array}$ & 1,124 & 14.9 & 74 & 2,493 & 2,220 \\
\hline Tonga & 104 & 0.8 & 144 & 353 & 3,380 \\
\hline $\begin{array}{c}\text { Trinidad } \\
\text { and Tobago }\end{array}$ & 1,344 & 5.1 & 261 & 20,664 & 15,380 \\
\hline Tuvalu & 10 & 0.0 & 327 & 36 & 3,700 \\
\hline Vanuatu & 240 & 12.2 & 19 & 662 & 2,760 \\
\hline
\end{tabular}

Source: World Bank.

*Does not include data on Cuba. 


\section{AFRICAN \\ EAST-ASIAN \\ AFFAIRS \\ THE CHINA MONITOR}

\section{China's relations with SIDS}

China's relationship with small island developing states and its recent deepening of the relationship derives from a mix of motives:

\section{Political Influence}

(a) Politically a small developing state can be important even to a superpower because of its strategic location, such as Panama, or for its support in international forums. Small island developing states have votes in the United Nations (UN) and other international organizations, and as such, can be useful allies. Thirty-seven small island developing states make up twenty-five percent of the membership of the UN. In addition, sometimes representatives of small island developing states are elected to important chairmanships; for example, Jamaica has chaired the Security Council of the UN on two occasions, as well as the G-77 and Non-Aligned Movement, and St. Lucia has held the presidency of the UN General Assembly.

(b) The primary force driving China's engagement with small island developing states is the unresolved dispute over the status of Taiwan and its diplomatic recognition by several SIDS (Chin; 2008, Bernal; 2010a, Fifita \& Hanson; 2011). Of the twenty-three countries that still recognize Taiwan, nineteen of them are SIDS. Twelve of these are in Central America and the Caribbean: Belize (1989), Dominican Republic (1957), El Salvador (1961), Grenada (1985-1989, 2005), Guatemala (1960), Haiti (1956), Honduras (1965), Nicaragua (1962-1985, 1990), Panama (1954), Saint Kitts and Nevis (1983), St. Lucia (1984-1997, 2007), and Saint Vincent and the Grenadines (1981). Six are in Oceania: Kiribati (2003), Marshall Islands (1998), Nauru (1980-2002, 2005), Palau (1999)

09 (c) Centre for Chinese Studies, Stellenbosch University

All Rights Reserved. 
and Solomon Islands (1983) and Tuvalu (1979). Sao Tome and Principe (1997) is the only country of this grouping in Africa that still recognizes Taiwan.

(c) The main instrument of political influence in the SIDS and other small developing states that both China and Taiwan employ is development assistance. Both countries use aid to maintain diplomatic allegiance and to preempt a small developing state's switching ${ }^{1}$ of allegiance, a practice described as "checkbook diplomacy ${ }^{2}$." Both China and Taiwan have been accused of going beyond the provision or promise of aid to interfering in international political affairs by making financial contributions to political parties favorably disposed to one or other of them in St. Lucia ${ }^{3}$ and Barbados (BBC News; 2008). Some SIDS governments have opportunistically sought to take advantage of the rivalry by having China and Taiwan compete for their diplomatic recognition. Such changes in allegiance can be very lucrative for the government of a small island developing state. When Dominica switched its diplomatic recognition from Taiwan to China, it benefited from the construction of a $\$ 17-$ million cricket stadium and a promise of $\$ 122$ million in economic assistance (Fieser; 2011, Sanders; 2011, Dominica Central; 2010). Some SIDS governments, for example, St. Lucia, Grenada and Nauru, have switched allegiance to capitalize on a better offer. In July 2002 Nauru switched its diplomatic recognition from Taiwan to China after a relationship of 22 years. Taiwan severed diplomatic ties. China agreed to provide $\$ 150$ million in aid. In February 2005 Nauru restored diplomatic relations with Taiwan, and China shortly thereafter broke off relations. There have been allegations that both China and Taiwan were involved in making political contributions and payments to government ministers (Dorling; 2011). 


\section{AFRICAN \\ EAST-ASIAN \\ AFFAIRS \\ THE CHINA MONITOR}

Some governments have changed their diplomatic allegiances in an opportunistic maneuver to extract more aid from either China or Taiwan. This has been accomplished on several occasions, but there are consequences to switching diplomatic allegiances. The loss of diplomatic recognition may prompt the donor country to be less accommodating and even antagonistic. Taiwan, for instance, decided to insist on Grenada's repaying a loan it had not been servicing, and to enforce its claim, instituted punitive actions. Had diplomatic recognition not been withdrawn, it is very likely that Taiwan would have renegotiated the payment schedule; instead it allowed its state-owned Export-Import Bank to pursue actions to recover the debt. The director-general of the Department of Central and South American Affairs, Wu Chin-mu, explained that Grenada was not considered for a renegotiation of its debt of $\$ 28$ million because the country was not a "diplomatic ally" (Barnacle Grenada; 2011). Taiwan was unsympathetic to pleas for lenience in which the government of Grenada claimed it was unable to pay the debt because of the economic damage Hurricane Ivan caused in 2004, the drop in tourism following the Sept. 11, 2001, terrorist attacks and the global economic crisis. Spokespersons for the government of Grenada stated to the media that Taiwan refused to renegotiate the loans because Grenada had severed diplomatic relations in favor of the People's Republic of China.

\section{Economic Expansion}

Although trade between China and small island developing states is infinitesimal and therefore economic motives remain secondary to political and diplomatic goals, there may be several reasons for

11 (c) Centre for Chinese Studies, Stellenbosch University

All Rights Reserved. 
economic interest:

(a) The enormous Chinese economy is an aggregation of businesses of different size, sophistication and ownership, and while the huge multinational corporations and state enterprises may spurn the scale of opportunities in SIDS, there are significant and appropriate opportunities for many relatively small firms. After all, business is business no matter how seemingly insignificant the opportunity. And although not great, in recent times, the expansion of exports has been steady with encouraging prospects for the future, possibly into technical and scientific sectors. To date the export of services has been almost entirely in construction, Some of these projects are surprisingly large for countries the size of SIDS. The Baha Mar tourist resort on the tiny island of New Providence in the Bahamas entails the construction of a 3,800-room resort (Ellis; 2012).

(b) As export markets, the small island developing states would be of no interest to an economy the size of China, but are of interest if they are sources of scarce raw materials. There is bauxite in Jamaica and Guyana, energy in Trinidad and Tobago, and fish stocks and offshore oil deposits in such small developing states as Belize. SIDS may also have high-end products or brands that could be exported to China. The rapidly growing middle class in China is exhibiting a taste for internationally renowned brands, which creates the possibility of importing such Caribbean brands as Jamaica Blue Mountain coffee (Collinder; 2009) and such world-famous rums of the Caribbean as Mount Gay of Barbados, Appleton of Jamaica and Angostura of Trinidad and Tobago.

(c) China has increasingly become a source of external financing, which 


\section{AFRICAN \\ EAST-ASIAN \\ AFFAIRS \\ THE CHINA MONITOR}

is evident in its increasing willingness to employ loans to secure construction contracts for infrastructure and buildings. For instance, China has financed the construction of hotels in the Bahamas and the Dominican Republic. For some SIDS the inflow of development financing from China or Taiwan has become almost indispensable, and these countries make a calculation of who will provide more aid. The countries that have chosen to recognize Taiwan have done so for pecuniary reasons, not ideological ones. Dr. Douglas, Prime Minister of St. Kitts and Nevis, explains: "We took an informed position that we would prefer to support Taiwan because Taiwan at the moment can bring the greater support in the advancing of the economic, social and political development of the people" (CUOPM; 2011). Prime Minister Gonzales of St. Vincent has expressed a similar rationalization to justify diplomatic ties with Taiwan (Jamaica Observer; 2011a).

(d) To date there has been very limited direct foreign investment emanating from China, but there are opportunities in tourism. Chinese firms are showing interest in a variety of sectors, including agriculture, where the attractions of economies of scale in countries like Brazil appear to preclude the limited size of operations in small island developing states. A Chinese firm has invested in cane cultivation and sugar production in Jamaica (Jamaica Observer; 2011, Jamaican Information Service; 2010) with the intention of exporting to China and world markets.

(e) The demand from the national markets of small island developing states may be limited, but these national markets could, under certain circumstances, be production platforms for exports to major national and 
Richard L. Bernal

global markets. For example, the small island developing states of the 15 -nation Caribbean Community and Common Market (CARICOM) could become entry points to the United States, Canada and the European Union (EU) because of preferential trade arrangements. These include the Caribbean Basin Economic Recovery Act (CBERA), CARIBCAN and the EU-CARIFORUM Economic Partnership Agreement with the EU. Central America and the Dominican Republic have access to the US through the Central American Free Trade Agreement. Costa Rica and China have concluded a free trade agreement (FTA), and although the Costa Rican market is very small (China Briefing; 2012), the agreement could become a template for Chinese FTAs with other SIDS. The FTA between China and Costa Rica, which came into effect in August 2011, provides for 60 percent of the two countries' products to enter each other's market duty-free immediately. Another 30 percent of products will be liberalized over periods between five to 15 years. The FTA is anticipated to boost a trading relationship in which China is already Costa Rica's second-largest export market (ibid.).

\section{Global reach of a superpower}

As a superpower, China wants to have a presence in all regions of the globe, and this disposition is the rationale for a foreign policy that encompasses relations with all countries regardless of size and remoteness. Hence even small island developing states have a place in China's foreign policy. Some small island developing states may be of security interest to China depending on their location and the deployment of US naval and armed forces and the location of US bases. Such is the case in the Pacific, where the US and China have differences 


\section{AFRICAN \\ EAST-ASIAN \\ AFFAIRS \\ THE CHINA MONITOR}

in what is regarded by both as a vital and contested sphere of influence. However, the SIDS of the Caribbean are not in a region where China, as an aspect of its national security policy, feels it must confront the United States physically. The political significance of some SIDS derives from the unresolved contention with Taiwan as opportunistic governments openly barter their political recognition for development assistance. China is willing to expend the resources necessary to try to eliminate Taiwan's claim to sovereign status, as well as the embarrassing and ludicrous anomaly of Taiwan still being recognized as the government of mainland China. Retaining and expanding support among the SIDS involves funds, aid in kind and technical assistance, which China can easily afford.

\section{Reciprocal Interest}

Some governments in small island developing states are anxious to cultivate and consolidate relations with Beijing as they take cognizance of China's increasing influence in global affairs. Because of their acute vulnerability (Briguglio; 1995, Atkins et al; 2001) SIDS will be well aware of the shifting of the center of gravity of the global economy to Asia, with China as the core. They will want to position themselves to benefit from new export opportunities, increased development assistance and access to loans, and to garner a share of the escalation of foreign investment.

External financing has become particularly important to SIDS' ability to endure the deleterious effects of the global economic crisis and the decline in development assistance to developing countries ${ }^{4}$ of all types. US aid to the small island developing states of the Caribbean amounted 
Richard L. Bernal

to $\$ 458.9$ million in 1985 , dropping to $\$ 136.3$ million in 1998 and recovering to $\$ 317.3$ million in 2006 , but with Haiti alone receiving 50 to 60 percent of the total (Bernal; 2001, Veillette et al; 2007). The need for non-traditional sources of external financing is especially critical for those middle-income SIDS that are heavily indebted (Hurley; 2010) with concomitant fiscal difficulties (Cas \& Ota; 2008, Sahay; 2005) and that are being - or have been - pushed toward graduation ${ }^{5}$ from the more concessionary development assistance facilities in international financial institutions and bilateral donor sources. In 2009 there were 14 SIDS with public debt/GDP ratios of over 60 percent, and another eight SIDS with debt/GDP ratios that exceed 10 percent. The public debt of St. Kitts and Nevis in 2010 was almost 200 percent of GDP (Hurley; 2010: 4).

Given the limited voice of small island developing states in international institutions (Bernal; 2011), they will need the active support of China to support of their goals and issues; for example, the demand for Special Differential Treatment in the World Trade Organization (Bernal; 2005, Von Tigerstrom; 2005). SIDS' acute economic vulnerability is compounded by their environmental fragility ${ }^{6}$ and proneness to natural disasters. In this regard, SIDS will want to encourage China's sympathetic awareness of their vulnerability to such imminent environmental threats as global warming. The leadership of small island developing states will increasingly look toward China to articulate and defend their concerns in international forums as China more comprehensively asserts itself in global economic governance. Such a role will not be new to China as in the past it supported the concept of exclusive economic zones, which is vital to the SIDS of the Pacific (Yang; 2011). 


\section{AFRICAN \\ EAST-ASIAN \\ AFFAIRS \\ THE CHINA MONITOR}

\section{Changing dynamics of China's Foreign Policy modalities}

The rationale that informs China's policy toward SIDS derives from the belief common to superpowers and several developed countries that they must be deployed diplomatically everywhere because their interests are wide-ranging. This outlook is also informed by the sense of the need to compete with the United States across the globe so as not to be at a disadvantage in economic or political positioning. The need for a presence everywhere is based on perceptions of both actual and potential interests. If you are not there, you cannot compete if and when there are new opportunities and unexpected developments (for example, changes of regime, the discovery of offshore oil deposits and the decision to purchase arms). The motivations behind the growing Chinese presence in SIDS will become more varied in the future as China becomes more integrated into the world economy and its trade and financial relations multiply and become more diverse. New issues that engage the United States and the European Union will inevitably become part of China's agenda in its role as a superpower; for example, providing troops for humanitarian and peace-keeping missions. China has provided troops for a humanitarian mission in Haiti $^{7}$ and its naval vessels have visited several $\operatorname{SIDS}^{8}$.

The modalities of China's foreign policy outreach to small island developing states could change in the future. One important factor is that relations between China and Taiwan have become less antagonistic, a consequence of their increasing economic integration and less-combative approaches of their respective leaderships. An unwritten informal truce has existed between Beijing and Taipei since 2008, when Ma Ying-Jeou

17 (c) Centre for Chinese Studies, Stellenbosch University

All Rights Reserved. 
Richard L. Bernal

was elected president of Taiwan, whereby both parties refrain from inducing countries to switch their diplomatic allegiances. Rosen and Wang explain: "In terms of trade flows, direct investment and portfolio investment and flows of people, cross-strait economic fundamentals are changing profoundly every day. In terms of Taiwan's export dependence on China, and final consumption in China as a share of these exports, the fundamentals are changing as well. The gap in technological capabilities between Taiwan and China is narrowing rapidly. Public sentiment regarding the importance of economic interests and the importance of transcending the past tensions also demonstrate significant changes" (Rosen \& Wang; 2011).

The declining importance of the China-Taiwan rivalry for diplomatic recognition could have serious repercussions for China's foreign policy toward SIDS in two respects. First, the decrease in tension with Taiwan could prompt China to considerably reduce its grants and development loans to SIDS, which could pose severe hardships for the SIDS involved, given that there is likely to be a concomitant reduction in aid from Taiwan. Second, China could switch the form of resource transfers from grants to development loans, which would raise external debt levels and require debt repayment. The indebtedness would provide significant leverage for China. Some SIDS would find either option, or a combination of both, very onerous Tonga's debt to China in 2009 was already the equivalent of 32 percent of GDP, and the debt of the Cook Islands and Samoa to China was 16 percent of GDP (Fifita \& Hanson; 2011). 


\section{AFRICAN \\ EAST-ASIAN \\ AFFAIRS \\ THE CHINA MONITOR}

China has become an important source of development financing for governments in SIDS. This financial nexus started with grants and contributions in kind as a prelude to low-interest development loans. The financial link is likely to strengthen and as indebtedness mounts will become an influential means of leverage for China. This is a reversal of China's position of leverage from the enticement of what it can do for a government in the future to that of being able to exert pressure based on what it has already done for that country. The fallout over Grenada's unpaid debt to Taiwan is an omen for the future. A new aspect could be that SIDS governments borrow by selling government paper to China, as has happened in Costa Rica. The government or the Central Bank of China could purchase bonds issued by governments in the Caribbean. This is new but not unprecedented, as China agreed to buy $\$ 300$ million in 12-year bonds at two percent from the government of Costa Rica as part of a deal for switching its diplomatic allegiance from Taiwan to the People's Republic of China (Bowley; 2008).

China has stated its willingness to afford debt cancelation to countries in Africa that are poor and are diplomatic allies (The Jakarta Globe; 2009). It has canceled Guyana's debt (Jamaica Gleaner; 2007), but that was related to its HIPC and least-developed status. This does not mean that SIDS should assume that they will be granted debt forgiveness, especially those that are middle income.

Foreign investment from China is likely to emerge as a new potentially dynamic avenue of external financial flows to SIDS. In 2008 foreign direct investment (FDI) from China amounted to $\$ 56$ billion (PRC MoC; 2010). The best prospects are in tourism, where it cannot be long before 
Richard L. Bernal

Chinese companies own and operate hotels in SIDS where tourism is the dominant economic activity; for example, receipts from tourism account for 49.8 percent of GDP in the Maldives and 86 percent of total export earnings in Antigua and Barbuda (WTO; 2004). China is expected to become the world's fourth-largest source of tourists by 2020, generating 100 million outbound tourists each year, according to the World Tourism Organization (WTO; 2006). The opportunity for tourist arrivals from China is visualized by small island developing states, which now have to promote effective marketing campaigns in China. While most SIDS possess few land-based resources to interest Chinese firms, the seafood stock (Powles; 2010) (for example, lobster catching and export from Antigua by Chinese companies) and undersea resources, especially oil and natural gas, are of interest,. There are also other opportunities; for example the Chinese company Bosai Minerals Group purchased a controlling stake of 70 percent in Omai Bauxite Mining, Inc. in Linden, Guyana, in December 2006 for \$100 million (Mining Top News; 2006). Some investment opportunities are based more on location than on size of country, as demonstrated by a $\$ 2.6$ billion port facility in Freeport, Bahamas, that was built and has been operated since 2000 by the Hong Kong-owned Hutchison Whampoa (Collins; 2001). Complant International, the foreign investment agency of the People's Republic of China, has purchased three sugar factories and leases of 30,000 hectares of cane -growing lands from the government of Jamaica. Complant will invest $\$ 156$ million in improvements in fields and factories over a four-year period (Douglas; 2011).

An intriguing future possibility is the expanded use of financial centers in the small island developing states by Chinese entities as they spread 


\section{AFRICAN \\ EAST-ASIAN \\ AFFAIRS \\ THE CHINA MONITOR}

their foreign investments globally. There have been increasing financial holdings in the Bahamas and the Cayman Islands, but these should not be interpreted as direct foreign investment in these countries. Sunderland and Matthews (2009) suggest that these funds are in the process of "round tripping" and therefore headed back to China as foreign investment.

China has gained much goodwill from financing and constructing major public infrastructure projects and buildings, but some resentment from local trade unions, construction workers, civil engineers and architects has arisen regarding the employment of Chinese workers. This sensitivity has been evident in the Bahamas, Jamaica, Trinidad, Barbados (Wilkinson; 2012) and Fiji (Blogspot; 2012). Another issue has been that some of the Chinese workers do not leave on completion of the projects on which they were employed. This has occurred in Antigua and Barbuda, Dominica, Guyana and Suriname. They are able to access concessionary financing from the Chinese government through state-owned banks and/or use their accumulated earnings to establish small businesses (African Globe; 2012) or buy local businesses. Such infiltration may be made where there are citizens of Chinese origin. Neither the governments of China nor the SIDS has an incentive to prevent this potential social friction since the former can easily lose workers and the latter are hesitant to offend their benefactor, as in the case of the vital dam in Fiji (Dornan; 2012). The US government is concerned about Chinese workers entering the United States from the Bahamas rather than staying in the Bahamas or returning to China (Dean; 2011).

21 (c) Centre for Chinese Studies, Stellenbosch University

All Rights Reserved. 


\section{Conclusion}

Relations with small island developing states are generally not important to large developed countries and even less important to global powers, unless the developing state is perceived to be in a strategic location from a military perspective. China, however, devotes significant attention to small island developing states, providing development assistance that, while small for China, has assumed considerable importance in these countries. The driving force behind China's engagement is the rivalry with Taiwan for diplomatic recognition by these small states. Small island developing states have a voice and have voted in international and regional organizations such as the United Nations and the World Health Organization. Of particular importance is the fact that most of the countries that grant diplomatic recognition to Taiwan instead of China are small island developing states. The SIDS that recognize China see the benefits in what for them is generous and vital development assistance, as well as have as an ally a superpower with some interest in and a willingness to defend their respective issues and concerns.

Whether China's particular interest in small island developing states continues and for how long depends on the intensity of the rivalry with Taiwan for diplomatic recognition. To the extent that there is an abatement of the rivalry or agreed truce between China and Taiwan, the importance of SIDS in China's foreign policy could wane, along with the development assistance to these countries. Such a contraction in Chinese aid would be a very serious loss to governments in several small island developing states. It is likely that, as a precaution, China would continue some level of aid, even if reduced, to SIDS in order to maintain 


\section{AFRICAN \\ EAST-ASIAN \\ AFFAIRS \\ THE CHINA MONITOR}

Issue 1

August 2012

the exclusion or prevent the reentry of Taiwan as a competitor for diplomatic recognition.

The relationship between China and small island developing states is dominated by development assistance that reflects the primacy of political motives; the relationship exists also because to date the potential for trade, direct foreign investment and tourism remains underdeveloped or undeveloped. The SIDS should be doing more to export to China, encourage Chinese foreign investment and promote tourism emanating from China.

\section{End Notes}

${ }^{1}$ This occurred after the 2006 coup when "China pledged large amounts of aid to Fiji in a bid to pre-empt Fiji making a switch to diplomatically recognizing Taiwan." See Mary Fifita and Fergus Hanson, "China in the Pacific: The New Banker in Town," Pacific Forum CSIS, Issues \& Insights, Vol. 11, No. 5, April 2011, p. 4.

${ }^{2}$ Use of grants and loans by a country to influence the policy of the recipient country. Disingenuously Taiwan has denied the use of checkbook diplomacy after the "truce" despite the donation of a jet plane to the government of Panama. Government denies "dollar diplomacy," Taipei Times. www.taipeitimes.com/News/front/archives/2009/12/../2003462118. Accessed June 26, 2012.

3 Taiwanese diplomat Tom Chou has been accused by the ruling St. Lucia Labour Party (SLP) of engaging in the internal politics of the country by channeling funds directly to government ministers and municipal bodies instead of through the central government accounts known as the Consolidated Fund. http://cananewsonline.com/news/full-news/politics-news/80558-st-lucia-politics -opposition-praises-outgoing-controversial-taiwanese-diplomat.html. Accessed

23 c Centre for Chinese Studies, Stellenbosch University All Rights Reserved. 
Richard L. Bernal

June 28, 2012.

${ }^{4}$ In 2011, members of the Development Assistance Committee (DAC) of the OECD provided USD 133.5 billion of net official development assistance (ODA), representing 0.31 percent of their combined gross national income (GNI). This was a $-2.7 \%$ drop in real terms compared to 2010. See "Development Aid to developing countries falls because of global recession," www.oecd.org/.../0,3746,en_21571361_44315115_50058883_1_1_...CachedYo

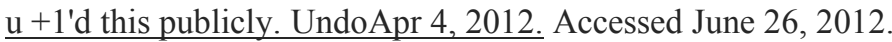

${ }^{5}$ There has been a push to exclude some small island developing states with high income per capita from grants and the most concessionary development assistance loan facilities. The view is gaining support in the European Union that Caribbean countries (all of which are SIDS) except Haiti should be graduated from development assistance. See David Jessop, "Bilateral Relations are the Present and the Future," Jamaica Gleaner, June 24, 2012.

${ }^{6}$ The environmental challenges that face small island developing states were recognized as an issue in urgent need of attention as long ago as 1994. In that year the United Nations hosted the Global Conference on the Sustainable Development of Small Island Developing States in Barbados, which formulated a Programme of Action for the Sustainable Development in SIDS (Barbados Programme of Action). This was followed in 2005 by the Mauritius Strategy on the Further Implementation of the Barbados Programme of Action. See United Nations, Mauritius Strategy for the Further Implementation of the Programme of Action for the Sustainable Development of SIDS, 2005: http://www.un.org/ smallislands2005/

${ }^{7}$ It has been suggested that "China seeks to use its troop contribution and UN Security Council veto as an instrument to pry Haiti away from Taiwan's grasp." Daniel P. Erickson and Janice Chen, "China, Taiwan, and the Battle for Latin America," The Fletcher Forum of World Affairs, Vol. 31, No. 2, summer 2007, p. 85 .

${ }^{8}$ China is engaged in an outreach to the military in Latin America. See R. Evan 


\section{AFRICAN \\ EAST-ASIAN \\ AFFAIRS}

THE CHINA MONITOR

Issue 1

August 2012

Ellis, "China-Latin America Military Engagement; Good Will, Good Business, and Strategic Position," Strategic Studies Institute, August 2011.

\section{References}

Anonymous. 2009. "Regime hiring Chinese workers while Fijians lose jobs." Blog: Discombobulated Bubu, 29 April. Online: http:// discombobulatedbubu.blogspot.com/2009/04/regime-hiring-chinese-workerswhile.html. Accessed July 5, 2012.

Atkins, J. P., Mazzi Sonia and Easter, Christopher D. "Small States: A Composite Vulnerability Index” in Peretz, D., Faruqi, R and Kisanga E. J., (eds.) 2001. Small States in the Global Economy. London: Commonwealth Secretariat, pp. 53-92.

Barnacle Grenada. 2012."Taiwan's Foreign Ministry Responds to Grenada Debt Questions," 28October 2011. Online: http://www.barnaclegrenada.com/ index.php/local-news/2110-taiwans-foreign-ministry-responds-to-grenada-debtquestions. Accessed: 28 June 2012.

BBC News. 2008. "China-Taiwan tussle in Bim politics," 8 January 2008. Online: $\quad$ www.bbc.co.uk/caribbean/news/story/.../080108 chinataiwan.shtml. Accessed: June 29, 2012.

Bernal, R. L. "Improving the Participation of Small Developing Countries in the Governance of the Multilateral Trading System" in Birkbeck, C. D. (ed.). 2011. Making Global Trade Governance Working for Development, Perspectives and Priorities from Developing Countries, Cambridge University Press, 2011, pp. 231-258.

- 2010. "Dragon in the Caribbean: China-CARICOM Economic Relations," Round Table, Vol. 99, Issue 408, June. pp. 281-302.

25 (c) Centre for Chinese Studies, Stellenbosch University All Rights Reserved. 
Richard L. Bernal

- 2006. "Special and Differential Treatment for Small Developing Economies" in Grynberg, R. (ed.). 2006. WTO at the Margins. Small States and the Multilateral Trading System, Cambridge: Cambridge University Press. pp. 309-355.

- 2001. "US-Caribbean Relations at the Dawn of the Twenty-First Century" in Bernal, R. L., Bryan A. T. and Fauriol G. A., The United States and Caribbean Strategies: Three Assessments. CSIS, Policy Papers on the Americas, Vol. XIII, Study 4. Washington, D.C.: Center for Strategic and International Studies. April. pp. 3-25.

- 1998. "The Integration of Small Economies in the Free Trade Area of the Americas," Center for Strategic and International Studies (CSIS), Policy Paper on the Americas, Vol. IX, Study No. 1.

Bowley, G. 2008. “Cash Helped China Win Costa Rica's Recognition,” New York Times, 12 September.

Briguglio, L. 1995. "Small Island States and Their Economic Vulnerabilities," World Development, Vol. 23, No. 9, pp. 1615-1632.

Charles, Mary G. 1997. A Future for Small States: Overcoming Vulnerability. London: Commonwealth Secretariat.

Chin, G. T. 2008. "China and Small States of the Caribbean: Responding to Vulnerabilities, Securing Developmental Space," Paper presented at The Centre for International Governance Innovation (CIGI) workshop, Tobago, 3-4 April, 2008 .

China Briefing. 2011. "China-Costa Rica FTA Comes into Effect," 2 August.

Online: www.china-briefing.com/china-costa-rica-fta-comes-into-effect.html. Accessed: 26 June 2012.

Commonwealth Secretariat/World Bank Joint Taskforce on Small States. 1999. "Small States: Meeting the Challenges in the Global Economy." Interim Report, 


\section{AFRICAN \\ EAST-ASIAN \\ AFFAIRS}

THE CHINA MONITOR

Issue 1

August 2012

October.

CUOPM. 2011. "St. Kitts and Nevis PM defends diplomatic relations with Taiwan," 28 January. Online: http://www.cuopm.com/newsitem new.asp? articlenumber=1553. Accessed: 18 May.

African Globe. 2012. "Chinese Influx Threatens Eastern Caribbean Businesses," 7 February. Online: http://www.africanglobe.net/business/chinese-influxthreatens-eastern-caribbean-businesses/. Accessed: July 5, 2012.

Collinder, A. 2010. "The Coffee Industry Board (CIB) targets China for new coffee markets.” Jamaica Gleaner, 22 November. pp. 10.

Collins, J. 2001. “China's Whampoa Ltd. opens port in Bahamas,” Washington Times, 20November.

Dean, B. 2011. "U.S. fears Baha Mar Chinese migration," The Freeport News, 14June. Online: http://freeport.nassauguardian.net/ national_local/65829088305882.php. Accessed 5July 2012.

Dominica Central. 2009. 'Dominica signs Framework Agreement with China," 5 September. Online: $\quad$ http://www.dominicacentral.com/general/community/dominica-signs-frameworkagreement-with-china.html. Accessed: 13 May 132010.

Dorling, P. 2011. "China, Taiwan buy influence with secret payments to Nauru politicians," The Sidney Morning Herald, 29August. Online: http:// www.smh.com.au/national/china-taiwan-buy-influence-with-secret-payments-to -nauru-politicians-20110828-1jgn8.html\#ixzz1z9jGofJq. Accessed: 29 June 2012.

Dornan, M. 2010. "Nadarivatu hydro scheme - A Chinese-Fijian partnership with pros and cons," East Asia Forum, 22 May. Online: http:// www.eastasiaforum.org/2010/05/22/nadarivatu-hydro-scheme-a-chinese-fijian-

27 (c) Centre for Chinese Studies, Stellenbosch University

All Rights Reserved. 
Richard L. Bernal

partnership-with-both-pros-and-cons/. Accessed: 5 July 2012.

Douglas, L. 2011. "Govt seals sugar deal with Complant. Chinese company investing US\$156m in industry," Jamaica Observer, 16August.

Ellis E. 2012. "The Expanding Chinese Footprint in Latin America. New Challenges for China and Dilemmas for the US." Asie.Visions 49. Paris/ Brussels: IFRI Center for Asian Studies. February. pp. 9.

Fieser, E. 2011. "Why is China spending billions in the Caribbean?" Global Post of Canada, 22April.

Fifita, M. and Hanson, F. 2011. "China in the Pacific: The New Banker in Town.” Pacific Forum CSIS: Issues \& Insights. Vol. 11, No. 5, April.

Hurley, G. 2010. "Achieving Debt Sustainability and the MDGs in Small Island Developing States," United Nations Development Programme Discussion Paper, 20 October. pp. 4.

The Jakarta. 2009. "China Promises $\$ 10 \mathrm{~b}$ in Loans, Debt Relief to Africa," 8 November. Online: www.thejakartaglobe.com/business/china...10bin...debt.../340401. Accessed: June 30, 2012.

Jamaica Gleaner. 2007. "China cancels debt owed by Guyana," 13 July.

Jamaica Observer. 2010. "J\$8b Sugar Divestment Agreements Signed Between Government and Chinese Investors," August 2. Online: http://www.jis.gov.jm/ news/opm-news/24875. Accessed: 16 March 2011.

Jamaica Observer. 2011a. "St. Vincent defends diplomatic ties with Taiwan," 4 May. pp. 17. "Making tourism work for small island developing states," Geneva: World Tourism Organization, 2004, pp. 12-13.

Cas, S. M. and Ota, R. 2008. "Big Government, High Debt, and Fiscal Adjustment in Small States." IMF Working Paper WP/08/39. Washington, 


\section{AFRICAN \\ EAST-ASIAN \\ AFFAIRS}

THE CHINA MONITOR

Issue 1

August 2012

D.C.: International Monetary Fund.

Mining Top News. 2006. "Bosai Mining acquires South America bauxite mining company,” 21 December. Online: http://www.miningtopnews.com/bosai -mining-acquires-south-america-bauxite-mining-company.html. Accessed: 23 November 2009.

Powles, M. 2010. "Challenges, Opportunities, and the Case for Engagement" in Wesley-Smith, T. and Porter, E. A. (eds.). 2010. China in Oceania: Reshaping the Pacific? London: Berghahn Books.

PRC Ministry of Commerce. 2010. Statistical Bulletin of China's Outward Foreign Direct Investment. Peoples Republic of China: Ministry of Commerce.

Rosen, D. H. and WANG, Z. 2011. The Implications of China-Taiwan Economic Relations. Washington, D.C.: Institute for International Economics. pp. 46.

Sahay, R. 2005. "Stabilization, Debt, and Fiscal Policy in the Caribbean." IMF Working Paper 05/26, Washington: International Monetary Fund.

Sanders, Sir R. 2011. "China's presence in Dominica," Caribbean 360, 28 April. Online: $\quad$ http://www.caribbean360.com/index.php/ opinion/389630.html\#axzzlKq0uuSct

Sutherland D. and Matthews B. 2009. "Round Tripping or Capital Augmenting OFDI: Chinese Outward Investment and the Caribbean Tax Heavens." Paper prepared for Leverhulme Centre for Research on Globalization and Economic Policy, University of Nottingham.

U.N. Department of Economic and Social Affairs. 2010. Trends in Sustainable Development. Small Island Developing States (SIDS). New York: United Nations. p. 1.

29 (c) Centre for Chinese Studies, Stellenbosch University All Rights Reserved. 
Richard L. Bernal

Veillette, C, Sullivan M. P. et al. 2007. "U.S. Assistance to Latin America and the Caribbean: FY2006-FY2008," CRS Report to Congress, Washington, D.C.: Congressional Research Service, 28 December 2007.

Von Tigerstrom, B. 2005. "Small Island Developing States and International Trade: Special Challenges in the Global Partnership for Development," Melbourne Journal of International Law, Vol. 6, Issue 2. pp. 402-436.

Wilkinson, B. 2007. "Influx of Chinese workers irks local unions," Caribbean360, 27 July 2007. Online: www.caribbean360.com/index.php/ business/12244.html. Accessed: July 5, 2012.

World Tourism Organisation. 2006. Chinese Outbound Tourism Market. Madrid: World Tourism Organization.

YANG, J. 2011. The Pacific Islands in China's Grand Strategy. Small States, Big Games, New York: Palgrave McMillan. pp. 9. 